\title{
「自己のために世界を捨つべし」 の引用をめぐつて
}

\section{高 原 信一}

序

\section{『マハーヴァスッ』( Mv i. 310. 11-12) に次のような韻文が出る1)。}

tyajed ekam kulasyârtham grāmârtham tu kulaṃ tyajet,

grāmaṃ janapadasyârtham ātmâthaṃ pṛthivīm tyaje.

「家のために人を捨つべし。村のために家を捨つべし。国のために村を，自己の ために世界を捨つべし。よいら韻文である。インドの仏教文献では，Mv のほ かに，『ディヴヤ・アヴァダーナ』(Divy) にも一回引用されている。とてろで, Otto Böhtlingk の Indische Sprüche I, St. Petersburg（初版1863）を参照すると, との同じ韻文が一般のインド文献に 8 回ほど出るととが知られる。更に新に出た Ludwich Sternbach の Supplement to O. Böhtlingk's Indische Sprüche (Wiesbaden 1965）は同じ韻文の出所を 18 ケ所ほど加えた。仏教以外のインド文献にし ばしば出るところから，恐らく仏教文献はそれら一般のインド文献に用いられて いたものを借用したものであろうと思われる。

原文について見ると, Indische Sprüche の初版と改訂版 St. Petersburg 187073 (Reprint, Wiesbaden 1966) とでは，特に a)の部分の読みが異なる。諸文献の 読みを比較してみて，どちらの読みを採るべきであろらか。むしろ初版の読みの 方が或いは本来の形ではなかつたろらか，というのが問題の第一である。

次に内容について，ての韻文の特にd）の部分「自己のために世界を捨つべし」 はどらいら意味でいわれているのであろらか。この最後の句は，『ルカによる福 音書』9，25「人が全世界をもらけても，自分自身を失いまたは損したら，なん の得になろらか。」を想起させる。逆の表現になつてはいるけれども，同じょう

1）『マハーヴァスッ』におけるとの韻文の引用については，筆者は下記論文の中で簡 単に紹介した。との論文はそれを出発点として, 更に諸文献にみられる同じ韻文の比 較研究に及んだものである。—「仏陀について——個と普遍の問題—」(『福岡大 学研究所報』第17号, 昭和48年 3 月, pp. 111-112 および p. 116 の註 (34) (39). 
「自己のために世界を捨つべし」の引用をめぐつて（高 原）

なととを言わんとしたものではなかろらかとも考えられる。はたしてどらいら意 味で用いられているのであろらか。夫ふの引用ケ所にあたつて，夫ふの文脈を比 較してみよう。特に，仏教文献とそれ以外の文献とでは，何らかの引用の相違が 認められるであろらか。もし相違があるとしたらそれは何故なのか。このよらな 点に注意しながら文脈を比較するのが第二の問題である。

\section{I，原文の比較}

$M v$ の文は前記の通りである。Indische Sprüche（初版）の読みは次の通りで 亦る。

tyajed ekaṃ kulasyârthe grāmasyârthe kulaṃ tyajet,

grāmaṃ janapadasyârthe ātmârthe pṛthivīm tyajet. 1066.

$M v$ の文と比較してみると，きわめて近い文である。 $M v$ tyaje と BHS 特 有の opt. 3rd sg の語形が見られる。 $M v$ では-ârtham とあるととろが後者で は皆-ârthe とある。ミーター上はどちらでも同じである。 $M v$ の写本B rthe とある。PTSD を参照すると, acc. atthan と共に loc, atthe の語形もあげ ているが，後者は用例も少く，前者の方が普通に用いられたものの如くである。 Skt ではどちらも屢々用いられる語形であるが， $M v$ では，恐らく $\mathrm{Pkt}$ に多く 用いられる方の-am をとつたものであろら。b) の部分で grāmârtham tu とあ つて, grāma を gen. の格変化とせずに, comp にして，代りに tu をれてい るのは，Mv だけの伝承である。これらの違いを除くと，Indische Sprüche（初 版）の読みにきわめて近い。次に, Indische Sprüche 改訂版の読みは，a）の部 分が次の通り変更されている。

tyajet kulârthe puruṣam——vs no. 2627 (1066). 他は初版と同じである。と の韻文には，以上のよらに大体三種類あることになる。すなわち，(1）Mv 引用 のもの, (2) Indische Sprüche 初版のもの, (3) 同書改訂版のもの, である。Mv のものは Indische Sprüche 初版のものにきわめて近いものであるから，それの 僅かな変異と見て，一応それに含ませて考えれば，大別二種類の読みがあるとと になる。Indische Sprüche 初版の読みと，同書改訂版の読みとである。筆者が 参照したものに限つて分類してみると次の通りである。

Indische Sprüche 初版の校訂と同じもの：Divyâvadāna, ed. by Cowe1\& Nei1, Cambridge 1836 (Reprint, Amsterdam 1970), p. 448, 11. 25-26=ed. by P. L. Vaidya, Darbhanga 1959, p. 291, 11. 18-19; Hitopadeśa, ed. by Peter Pete- 
rson, Bombay Sanskrit Series xxxiii, 1887, 115; Pañc [The Panchatantra ed. by Johannes Hertel : HOS vol. 14, 1915] I. 118-d) svâtmârthe; Pañc Rec vol. 1 〔The Panchatantra Reconstructed by Franklin Edgerton: AOS vol. 3, 1924] I. 117d) (sv)âtmârthe; $M B h$ 〔The Mahäbhärata ed. by Vishnu S. Sukthankar〕 1. 107. 32 (Fasc. 5, Poona 1931, p. 479)—a) $\mathrm{K}_{1.2 .4} \tilde{\mathrm{N}}_{3} \mathrm{~T}_{1} \mathrm{G}_{2-5}$ tyajet kulârthe puruṣam,, - c) $\tilde{N}_{2}$ grāmān,-_) $S_{1} K_{1}$ svâtmârthe.

Indische Sprïche 改訂版の校訂と同じもの: MBh 5.37. 16 (Fasc. 9, Poona 1937, p. 169)—a) Dn ${ }^{2}$ kulârtham, $K_{1.4}$ tyajed ekam kulasyârthe, —d) $\mathrm{D}_{6}$ ātmârthaṃ, $\mathrm{C}_{4}$ hy ātmârthe; $M B h$ 5. 126. 48 (Fasc. 10, Poona 1940, p. 457)-a) $\mathrm{D}_{3.4}$ kulârthạ̣, $\mathrm{K}_{\mathbf{1 . 2 . 5}}$ Ds $\mathrm{D}_{7.8 .10}$ tyajed ekạ̣ kulasyârthe; $M B h$ 2. 55. 10 (Fasc. 14, Poona 1944 , p. 272) — a) $\mathrm{K}_{1} \mathrm{D}_{6}$ kulârthạ̣, $\hat{S}_{1} \mathrm{~B}_{1-3.6} \mathrm{D}_{1.2}$ tyajed ekam kulasyârthe, —d) Ś S $_{1}$ svâtmârthe, $G_{2}$ hyā $\bar{a}^{\circ}$ (for $\bar{a}^{\circ}$ ).

写本の読みに違つたものがある場合，どの読みを採るかはむずかしい問題であ る。読みを決定するのは必ずしも写本の読みの数ではない。系統の同じ多くの写 本の読みが一致したものを伝えていても，他方，数は少くても，系統を異にする いくつかの写本の読みに一致したものがあれば，むしろこの少い読みの力を採る のが原則とされる。 $M B h$ の写本の読みはIndische Sprüche 改訂版の校訂を支 持するもののよらである。しかし，いずれのケ所でも Ind. Spr. 初版の校訂を支 持する写本がいくつかある。従つて $M B h$ では両方の読みがありらることになる。 ところが，同じブラフマニズム文献に含まれる Pañcatanta, Hitopadeśaは, Ind. Spr. 初版の校訂を伝え, 全く異質的と思われる仏教文献 Divyâvadāna も 同書初版の読みを伝えている。他にも参照すべき文献が残つているけれども，以 上見た所からすると, Ind. Spr. の読みをむしろ本来の形として出した方がよい のではないかと思われる。もつとも, いずれの読みにしても, ミーターの上で不 都合はないし，内容も全く同じである。

\section{II 文脈の比較}

まず，仏教文献から始めよう。 $M v$ では Mālinī の章 (i. 301. 3-317. 3) に出る。 この章の梗概は次の通りである。カーシ一国王クリキンの娘マーリニーは, 父の 言いつけに従つて，毎日二万人のバラモンに食事を差上げていた。ととろが，娘 は迦葉仏に帰依してしまつた。彼女はバラモンたちに食事を差上げることをやめ て，仏陀および仏弟子たちに食事を差上げるようになつた。バラモンたちは立腹 
して，集会を開いた。マーリニーを死刑にするといら決議がなされた。地方巡行 をしていた王は，その知らせをらけて警く。家系を愛惜するならば，マーリニ一 を差出せ，とバラモンたちは言う。娘を差出さなければ自分の生命はないし，娘 の生命はいずれにしてもないであろう，と王は考える。一一その次に，今問題の 韻文が入る。一そてで，王は娘をバラモンたちに差出すととにする。マーリニ 一は，最後の願いとして，バラモンだちに一週間だけの命乞いをする。その願い は許される。その一週間，マーリニーは仏陀および仏弟子たちに供養をする。そ の間に，王を始め，町中のほとんどの人は仏陀の説法を聞いて法眼清浄なるとと を得た。マーリニーのおかげで我ふは法眼を得ることができたのであるから，彼 女は我々の善知識である。彼女が殺されるのなら，彼女の代りに我ふが「自己」 (ātman) を捧げよら。(p.311, 11.6-7: api nāma vayaṃ ātmānaṃ parityajeyāma na mālinīm) とらいつて, 町の人たちは大挙バラモンたちの所へおしかける。その様 子にバラモンたちは驚いて，決議を変更する。悪いのはマーリニーではなくて， 迦葉仏である。彼を死刑にすべきである。こらしてマーリニーは釈放され，刺客 が迦葉仏の所へ差向けられる。多くの刺客が次々に送られるけれども，彼らは反 つて仏陀に教化されて慢心を捨て，聖法に住せしめられる。もつとも，千仏が教 化しても，法を理解しないバラモンたちもいた。大体てのよらな筋である。 この文脈からすると，「自己のために」といらのは，王がただ自分の生命が惜し いために，といら意味で，つまり「利已的な自己」の意味で引用していると考え られる。そして，「世界」(prthivī) といらのは「大地」であり，「女神」(devī) と して人格化される語である。devīiまた「女王」「王女」「婦人」を意味する。 それで，「prithivī を捨つべし」といら時，王女を捨てるてとと脚けて用いたもの のよらに思われる。「自己のために世界を捨つべし」といらと，あるいは「真実 の自己の実現のためには一切のものをなげらつべし」といらような次元の高い意 味ではないか，とも考えられるけれども，以上の文脈からすると，どらもその意 味では使われていない。文字通り「自己のために世界を捨つべし」である。ただ そのさい，言葉の掛け遊びをして，世界 (prrthivi) と王女（devi) とをかけて， 「自己のために prithivī を捨つべし」とある，そてで王は王女マーリニーを捨て たといらのである。

このマーリニーの章では, バラモンたちは「高慢で, 尊大な, 移り気の, 野卑 な人たち」(p. 305) として描かれるのに対して，仏弟子たちは，「悪を離れた…… 物静かな動きの……修養のできた人たち」(pp. 305-306) とあつて，バラモンたち 
(66)

「自己のために世界を捨つべし」の引用をめぐつて（高 原）

は対照的に，悪しき者として描かれる。そのバラモンたちの教に従つているとて ろでは，王は「自己」のために娘をも捨てょうとする。てれに反して，仏陀の教 をうけて法眼を得た人たちは，善知識のためには「自己」を捨てる。このような 意味で，仏教の側からブラブマニズムの側を攻撃するために引用した韻文である と理解される。

次にもら一つの仏教文献 Divy での引用を見る。話の筋は次の通りである2)。 王と王子に夫々司祭がついている。王子は，父が亡くなつて王位をついだら，お 前を王の司祭にしてやると，王子の司祭に話す。王の司祭がてれを聞いておつた。 彼は，王位の継承と司祭職の継承ができないようにしようとたくらむ。王の司祭 は，たまたま王の夢を占ら。それは王が位を追われる前兆である。かいかくしか ビかのバラモンの呪法を行わなければならぬ。そのために，てれてれのものを用 意せよ。その上，キンナラの脂肪で香を焚かねばならぬ，といら。王はそれはむ ずかしいといら。王の司祭は「得にくいものが実は一番手に入りやすい。マノー ハラーはキンナリーではありませんか」という。王は「司祭よ，そのように言ら な。(マノーハラーは王子の愛妻であって) 王子の生命がかかつているのだから。」と いら。てれに対して司祭は「王様，てのようにいらではありませんか」といつて， 例の韻文を引く。次に，「思虑あるこの王子の主権を堅固な心をもつてなくしな さい。とのマノーハラーを殺しなさい，他の女性を作ることは出きるのだから。」 といら別の韻文が入り，「自己を求めるものたちはどんなととでもしないてとは ない。という。しかし，キンナリーのマノーハラは無事に逃がれ，最後はめで たく王子と結ばれ，王子も王位を継承するといら筋である。「自己のために世界 を捨つべし」の句は，ててでも，バラモンの側での主張として引かれている。そ して，我が身の安全のためには，王はどんな大切なものでも捨てようとするとい ら意味で，仏教の側からは否定さるべきてと，非難さるべきてととして引用され ている。

以上，インド仏教文献の用例をみてきた。次に，仏教以外のインド文献の用例 に移る。まず，『パンチャタントラ』の例である3)。I. 8: ライオンの家来たちと

2）奈良康明訳「スダナクマーラ・アヴァダーナ」（世界古典文学全集 6 『仏典』I, 筑 摩書房, 昭和 41 年 5 月, pp. 297-314, 特飞 p. 306 参照。

3) The Panchatantra Reconstructed by Franklin Edgerton, vol. 2 : Introduction and Translation (American Oriental Series vol. 3) American Oriental Society 1924, pp. 308-311 参照。 
「自己のために世界を捨つべし」の引用をめぐつて（高 原）

ラクダの物語である。ライオンに三人の家来がいた。ひよら，鳥，山犬である。 王様は，たまたま隊商に捨てられたらくだを見つけて，てれを保護してやる。す なわち，無畏施（abhaya-pradāna）を与えた。王様がある時，象の牙で傷をおら。 飭食を捕えるととができない。そこで，烏は王様に向つて，ラクダを殺して食べ ればよい，といら。ライオンは腹を立てて，無畏の施しより大なる布施はない， どらしてラクダを殺せよらか，といら。烏は次のよらに言う。正しい行為につい ての王様の理解は偉大です。しかし，もら一つ大切なととがあります。すなわち， 偉大な聖者の言葉です。善いととのためには悪も行われると。又，こらもいわれ ます。とらいつて, 例の韻文をあげる。しかも, 王様が手を下さなくても, よい考 えがあります。ラクダは自分から身を捧げるでしよら。こらいつて，烏は仲間の 所へもどつて相談する。王様は飢えのために今にも死にそらである。我々は自己 を捧げよう。てら相談して王の前に行く。ラクダもその中に居た。烏がまず言う。 私の肉を食べて下さい。お前の体は小いから食べてもしよらがない。山犬もひよ らも次々に同じよらにいら。答は同じである。最後にラクダが，私の体で貴方の 生命を救つて下さい，と。その言葉が終るか終らないらちに，ひようと山犬はラ クダに襲いかかつて，二つにさいた。たちどてろにラクダは食べられてしまつた。 こらいら筋である。もともと肉食と菜食が共存するのが無理である。原則論だけ では生きることができない。王は自分のために，大切なものでも場合によつては 犠牲にしなければならない。そらいら意味で，ての韻文を引用している。やむを えないとととして肯定する例である。

次に,『ヒトーパデーシャ』では，二つの韻文にはさまれて次のよらな形で出 てくる。岩波文庫本の訳文を参照すると次の通りである。

(沜と鼠と烏と亀とが友情を得る。鼠が亀に身の上話しをする。そのあとの文である。) 「従つていかなる場合にも，それぞれの状況に適するよらに，行為に節度を設け るとと (kāryapariccheda) が大切だ。

（114）この世に生ける人にとり，法とは凡ゆる生類を憐むとと（bhūta-dayā）に ほかならず。楽とは健康, 更にまた, 愛 (sneha) とは心の温かさ。而して学問知 識とは節度 (pariccheda) を言らにほかならず。

実に

（115）家のためには個人を捨て，村のためには家を捨て，国のためには村捨て ん。さはさりながら，自らのためには世界も捨つべきぞ。

また， 
「自己のために世界を捨つべし」の引用をめぐつて（高 原）

（116）得やすき水をとるべきか，危険を冒すも美食か、と，熟慮重ねて知り てけり。"節度の存するととろにで (vicārya khalu) 真の安らぎあるべしミと。

私はてのよらに考えて，誰も住んでいない森へ来たのです。その後私の運が向 いてきて烏さんから友情に恵まれました。」」)

ここでは，例の韻文引用の文脈はそれほどはつきりしていないけれども，要す るに，何事も節度をわきまえて，場合場合に応じて適切な行動をしなければなら ぬ，といら筋の中で引用しているものであつて，ててでも，ての韻文は肯定する 立場で引かれている。尚，話の主人公は森の動物たちであるけれども，その話を 語るのはヴィシュヌシャルマといら学者であり，彼が王子たちに心得として話し ている点に注意しなければならない。

最後に，『マハーバーラタ』における引用を見てみよう5)。前記の通り4 回引用 されている。まず第一は，MBh. 1. 107. 32 である。この韻文は Ādi-parvan の 中の Sambhava-parvan に出る。王子 Duryodhana の誕生にまつわる物語りであ る。Dhṛtarāṣṭra 王の妃 Gāndhārī は，百人の立派な王子が欲しいと願をかけて， その願はやがてかなえられるととになる。しかし，彼女は 2 年間難産に苦しむ。 その間に，弟の Pāṇdu 王の妃 Kuntī の方に先に，旭日の如くに立派な王子 Yudhișțira が生まれた。そのてとを聞いて Gāndhārī は大変悲しむ。やがて彼 女は肉塊を生む。Vyāsa がやつてきて, 処法を授けて去る。その処法通りにして 彼女は, その肉塊から，Duryodhana を長子とした百人の王子と一人の王女を得 た。ところが，Duryodhana は生まれるとすぐに，ろばのよらな泣き声をあげた。 その他不吉なととがおこる゙์。Dhṛtarāșțra 王は伯父 Bhīṣma および弟で賢者の Vidura を呼んでたずねる。「Yudhișthira 王子の方が年長であるから，彼が我ふ の家柄を継ぐ者である。彼が王位を得るのが自然である (svagunato)。それについ て，我々は何も言らととはない。しかし，そのすぐあとに生まれた彼 Duryodhana は王となることはないのだろらか。こらいら場合に一体何が正しいのか我れ

4）ナーラーャナ著金倉圓照, 北川秀則訳『ヒトーパデーシャ一一処世の教え——』岩 波文庫，昭和43年，pp. 18一特に pp. 60-61 訳文参照。

5）英訳としては逐語訳した下記のものを参照した。その章節の番号は Bombay Edition のそれに一致する。—-The Mahabharata of Krishna-Dwaipayana Vyasa, Translated into English prose from the original Sanskrit Text, By Pratap Chandra Roy, Oriental Publishing Co., Calcutta-12, Second edition, 12 volumes, 年号なし。

6）凶相についての記述はプーナ版の本文には出ない。脚註にボンベイ版の読みとして あげている。 
「自己のために世界を捨つべし」の引用をめぐつて（高 原）

に語れ。」この言葉が終ると, 山犬や恐ろしい野獣たちが不吉を予告するように 咆えた。この恐ろしい凶相を見て，バラモンたちと賢者 Vidura とは王に申し上 げた。「ての貴方の王子は家系を滅ぼす者となることは明らかである。彼を捨つ れば平安があるが，育てれば大なる失策となるであろら。大王よ，貴方にはまだ 九十九人の王子があるではないか。一人（を犠牲にするてと）によつて世界と家 柄の安穏を得よ。」一そのあとに次の韻文が入る。一ー゙ラモンたちや賢者 Vidura はこのよらに言つたけれども，Dhṛtarāșțra 王は，我が子に対する愛情か ら (putra-sneha-samanvitah)，その忠告を聞き入れなかつた。とのような筋である。 この韻文は，賢者 Vidura およびバラモンたちの主張として出る。「家系のた めには一人を捨つべし」といらとと, つまり王子 Duryodhana を殺すととは，伝 統的バラモンたちの側からすると，やむお充ないとととして肯定されている。し かしながら，Dhṛtarāștra 王は，その言葉に従おうとしなかつた。とのことが， 実は禍根となつてバーラタ族の同族相い食む大戦争が展開するてとになるのであ る。

第二は，MBh．2. 55. 10 である。Sabhā-parvan の中の Dyūta-parvan『賭博 の章』に出る。従兄弟同志である王子 Duryodhana と王子 Yudhișthira とが賭 博をする。Duryodhana の方はその叔父 Śakuni が代りに采を投げる。代役をす るとと自体不正行為である。Śakuni は賭博の名人であつて，何べんしても， Śakuni は不正をして勝つてしまう。それでも Yudhișțhira はやめようとしない。 あらゅる財宝を賭け，軍隊までも賭ける。そこで賢者 Vidura は Dhṛtarāșțra 王 飞忠告する。「王よ，私の言葉は苦言であろらが，王子 Duryodhana は貴方たち 皆の死の原因となるであろう。山犬が Duryodhana の姿をして貴方の家に住んで いる。一羽の鳥 (Duryodhana) の代りに，てれらの孔雀 (pānḍava 族)を買えよ。 山犬の代りに，乙れらの虎を買えよ。一その次に例の韻文が来る。

ここでも，第一の用例と同じょうに，「王は家のためには王子 Duryodhana を 殺せ」といら意味で引用している。

尚とのあとの話の荒筋を付記すると次の通りである。賢者 Vidura は, Śakuni を帰らせるように Dhṛtarāșțra 王に忠告する。しかし，その忠告は聞き入れられ ない。Śakuni は更に賭をしかける。王子 Yudhișțira はその誘いにのつてしま う。とうとう国を賭ける。弟たちを，自分自身を，妻 Draupadi までも賭けるは めになる。Śakuni は常に不正手段を用いて勝つ。最後に Draupadī は, Dhṛtarāștra王から三つの願いごとを許される。しかし，彼女は，クシャトリャの妻は二 
つの願いでとを願らべきものであるから，といつて，一つは，Yudhișțira を自 由にすること，二つには，弟たちを自由にするてと，と二つの願いでとだけを願 つて許される。こうしてしばらく事は収まる。

第三の用例は，MBh. 5. 37. 16 である。Udyoga-parvan の中に出る。第二の 用例と同じように，賢者 Vidura が Dhṛtarāșțra 王をさとす言葉として出てくる。 前後の梗概は次の如くである。王子 Yudhișțhira は賭博にふけつて，王子 Duryodhana から国を取られてしまう。両軍に分かれて夫ふの軍隊が集結する。Dhṛtarāșțra 王は Sañjaya を使者として, Pāṇḍava 族の様子を調べにやる。王子 Yudhișthira はあえて戦ら積りはない。たぐ王国の一部を我々に与えてくれればよい， と使者に伝言する。王子 Duryodhana はあくまで戦おうとする。父 Dhṛtarāṣtra は眠られず，悩み，賢者 Vidura の意見を聞く。Vidura は，愚者の行為，賢者 の行為はかくかくであると，一般に処世訓を語る。その中で，「快い言葉を語る 人は多い。しかし，不快であるが薬になる言葉を喋る人も聞く人も少い。主人の 耳に快いか不快かにかかわりなく，正義だけを考えて，苦言ではあるが薬になる ととを言う人は，本当に王の力の足しになる。うの次に例の韻文が入る。この 章 (MBh. 5. 37) の終りには，Dhṛtarāṣțra 家は森，Pāṇdu 家は虎として，ある いは前者は蔓として，後者は獅子として共存せよ，という。この章だけからする と，例の韻文はただ一般論を言つているようにもきてえる。しかし，あとの章 (MBh. 5. 39. 4 の脚註，おょび 39.7）を参照すると，「Duryodhana が生まれたと き，彼を捨てよと私は言つた。貴方は一人の息子を捨てるべきである。彼を捨て ることによつて，百人の息子の繁栄を得るであろう。捨てなければ破滅が百人の 息子を襲らであろら。……Dhrtarāșțra 王は言う。貴方の言うことは全て賢者に よつて承認されている。そして私の未来の善のためである。しかし，私は息子を 捨てることは到底できない。正義のあるところに勝利ありといわれるけれども。」 とある。従つて，ててでも，賢者 Vidura が，Dhṛtarāșțra 王に向つて王子 Duryodhana を捨てよという意味で引用しているものである。

最後は $M$ Bh. 5. 126. 48 である。最初の用例はバラモンたちと賢者 Vidura の 言葉であり，次の二つが賢者 Vidura 一人の言葉であつたのに対して，ての場合 は Kṛṣna の言葉として出る。前後の梗概は次の如くである。Krṣna は Kuru 族 の集会で Duryodhana を詰問する。「賭博という形で災難の源を作り出したのは お前である。……国の分け前をPāṇḍava 族が望んでいるのにお前は与えようと しない。….雨親，Bhịṣma，Droṇa，Vidura がたびたび，和睦せよというのにお 
「自己のために世界を捨つべし」の引用をめぐつて（高 原）

前は和㓐しない。….」Duhśsāsana は Duryodhana に言ら。「貴方がもし Pāṇḍava 族と和睦しようとしないなら，Kuru 族たちは，Karṇa と私と貴方を縛つて Pāṇḍava 族に引き渡すでしよう。Bhīṣma と Droṇa と貴方の父上が三人を Pāṇḍa 族に引渡すでしよら。」Duryodhana は怒つて座を立つ。Kṛṣna は語る。「神々と 阿修羅たちとが戦おちとしたとき，神々，阿修羅たち，人間たち，ガンダルヴァ たち，竜たち，羅刹たちがこの闘いでたがいに殺し合らことになる。そこで，か つて Parameșthin は Dharma に命じて，Daitya 族 および Dānava 族を縛つて Varuṇa に差出させたと同じように，Duryodhana, Karṇa, Śakuni, Duḥ́sāsana を 縛つて Pāṇḍava 族に引渡せ。一例の韻文が入る。一Duryodhana を縛つて Pāṇdava 族と和睦せよ。貴方のためにクシャトリヤ族が滅ぼされるととのない よらに。」こらいら文脈である。

$M B h$ における用例は，いずれも，一族の繁栄のためには一人の悪人（または 数人の悪人）を犠牲にするのもやむをえないではないか，と肯定する立場で例の 韻文を引用している。

結、び

以上，一つの韻文をめぐつてその用例にあたり，文脈を比較してみた。その結 果をまとめると，大体次のようなととがいえると思われる。Hitopadeśa の場合 を除くと，いずれも王についての言及である。もつとも，Hitop. の場合も，王 子たちにその心得として話す中に出てくるものであるから，結局いずれも王の心 得に関することである。つまり，政治的レベルでの言及であるといつてよいと思 われる。王は，一族のためには場合によつては一人を捨てねばならぬ，ないし， 自己のためには，もつとも大切なものでも場合によつては捨てねばならぬ。そら いら意味で用いられている。文脈を比較してとり出されるもつとも興味ある点は, 仏教文献とブラフマニズム文献とで, 引用の仕方に顕著な違いが認められるとと である。ブラフマニズム文献では，ての韻文の主張はやむおえないとととして是 認する立場にある。これに対して，仏教文献ではこの韻文を非難する意図をもつ て引いている。もともと，ブラフマニズムは梵我一如を旗じるしとして，真実の 自己の実現をめざすものであるのに対して，仏教は，利已的自我，我執，我所執 といつたものを否定する，いわゆる無我を標榜するものである。それはまた，法 飞導いてくれた人のために自己を捨てよらとする。法尊重の立場でもある。一方 抙 (ātman) の陣営であり，他方は無我（anātman）の陣営である。とのよらな 
思想的立場の相違が，この一つの韻文の引用をめぐつて，きわだつた違いを示し ているものといえる。

また，仏教文献にその韻文の用例が少いとと，しかも引用する場合，否定的に それを用いている点などからして，ての韻文は本来ブラフマニズム文献に用いら れていたものであつて，それを仏教文献も借用して引用したものと思われる。そ してまた，「自己のために世界を捨つべし」は，決して，真実の自己の実現のた

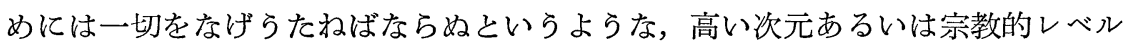
で引用しているものではない。てのようなととがいえよう。

なお蛇足を加えると，上に述べてきたような事実を取り出すてとができたあと でも，筆者はなお，「自己のために世界を捨つべし」の句は，始めにふれたよう に『ルカによる福音書』の主張に近い意味を本来意図していたのではなからうか， との想像を捨て去ることができない。あるいは，高い宗教的な次元での用例が他 に見出せないものであろらか7)。

7） Pratap Chandra Roy の英訳から「自己のために」の部分をとり出すと次の通りであ る。 'for the sake of the soul', 'for the sake of one's soul', 'ditto', 'for the sake of one's self.' 